\title{
African spiritual phenomena and the probable influence on African families
}

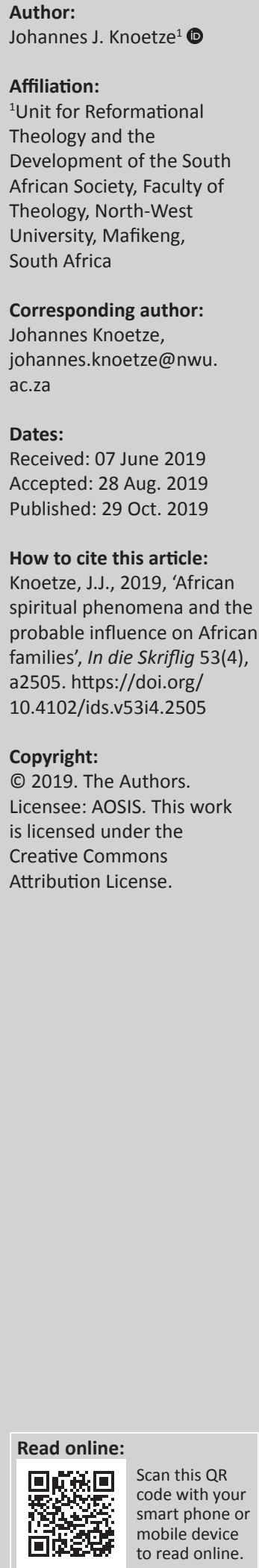

\begin{abstract}
African spirituality is a holistic concept that stemmed from the historical, cultural and religious heritage of Africa, and includes among others, folktales, beliefs, rituals and culture. African spiritualities must be understood as originated from Africa's soil, but also developed through contact with people from other countries and continents. The African independent or indigenous churches play an important role in the establishing of African Christian spiritualities. This article distinguishes and gives attention to the influence of African traditional spiritual phenomena as well as a 'globalised Africa spiritual' phenomenon on African families. When the influence on African families are discussed, it is done from a Christian point of view, and for this reason the article concludes with the role of the missional church and parents in the spiritual formation of their children.
\end{abstract}

Keywords: African traditional religion, spirituality, globalisation, families, missional church

\section{Introduction}

The article focuses on the African family and the influence of African spiritualities on the family. Although the article refers to children (ages 0-14) and emerging adults (ages 15-34), the focus is on the family for the following reasons: Firstly, African spiritualities find itself in and are related to the oral African tradition. It is also conveyed to children by different family members, including grandparents, parents, extended family members and siblings. Secondly, working from a covenantal reading of Scripture, children and especially the spiritual formation ${ }^{1}$ of children, may not be discussed as something happening outside the family. A third important reason is that family life has changed drastically and radically within the process of industrialisation, urbanisation, globalisation, the technological revolution and the new found democracies in Africa and especially in South Africa. It is along these lines that the article wants to answer the question: What are the influences of African spiritual phenomena on African families? The article will do a critical hermeneutical analysis of the influence of the phenomena of African spiritualities on African families.

\section{An understanding of spirituality}

Some scientists view Africa as the mother continent of the entire world's people. Africa has a very rich heritage of what previous generations of African people thought, did, experienced and passed on to their children. However, this heritage is not uniform. Mbiti (1991:4-10) describes the heritage under the following three headings: firstly, historical heritage - where he describes African life in general; secondly, the cultural heritage - the way people act and live as well as their physical and intellectual achievements; and thirdly, he refers to religious heritage. He indicates that religious heritage may also be viewed as culture. According to the researcher, these three distinctions are so closely related that it can be captured under the umbrella term spirituality. Spirituality is not always religious but is always concerned with the quest for meaning of life. When such a quest involves an explicit reference to God or the Divine, then that spirituality is religious (Amanze 2011 ; Wellman, Perkins \& Wellman 2009:1):

'Spirituality' then is not defined by an explicit set of religious beliefs or practices. On the contrary, spirituality does not need religion at all to define itself ... Spirituality, therefore, is more about how people identify themselves, how they view the world, interact with others, and make decisions.

Thinking about spirituality in Africa, this understanding of spirituality is most applicable, as it complements the holistic African worldview.

According to this understanding, Africa is a continent with a vast plethora of spiritualities - some of which originated on African soil and others developed through contact with people from other

1.Please note that this article is not about spiritual formation, but the influence of different spiritualities in Africa on the family. 
countries and continents. It needs to be stressed that there is not just one single African spirituality, although many of the characteristics of the African spiritualities are alike, but it may have different interpretations. It is in this regard that Nürnberger (2007) states:

Religions are not a fixed and watertight systems of meaning, but subject to internal change and external impact. Moreover, if genuine, they respond to changing needs and perceptions of reality. Religious assumptions are always in historical flux, integrating elements from outside, reacting to new experiences, producing new intuitions. What matters in particular cases is not the ostensibly 'original' form of an African spirituality, which may or may not have been practised centuries ago, but its present, living form. (p. 35)

An important remark to frame this article is defining who is considered African. Is it defined by geography (the continent)? Alternatively, is it defined by skin colour, or what criteria is used to define an African? Within this article, an African will be defined in terms of spirituality according to the understanding of Wellman et al. (2009:1) as indicated above. Therefore, it needs to be noticed that, in discussing Africa's spiritual phenomena today, we need to be aware of and distinguish between: (1) the original traditionalist religion; (2) the impact of Christianity; (3) the impact of modernity; and (4) the current postmodern culture. Although original African traditionalism is rarely found today, together with the impact of Christianity, it still influences the worldview of many Africans, for example over 12000 young Africans participated in initiation schools in Mpumalanga province in South Africa during 2018. Most African people are somewhere on the way to modernity in tandem with large-scale urbanisation. Especially young (African) people in the cities have largely become part of the global modernpostmodern African culture. The same is largely true for the political and economic elites. Aware of these distinctions that need to be made, this article will mostly attend to the original traditionalist beliefs that still affect the African families. Equally important, an influence on African families, covered in this article in a bird eye view is the impact of modernisation and post modernisation or globalisation.

\section{Africa's spiritual phenomena: A description Introduction}

Africa spirituality can be described or understood from the following characteristics: beliefs, practices, ceremonies and festivals, religious objects and places, values and norms as well as religious officials and leaders (Mbiti 1991). Amanze (2011:13) says:

\footnotetext{
African spirituality as [is] a scenario of tension between local and foreign forces utilizing spiritual means in order to try and resolve that tension. African spirituality in this case is not a fixed collection of spiritual means which might be labelled specifically African. Many such spiritual means are imported intercontinentally from outside Africa from such world religions as Christianity and Islam. All in all ... in principle African spirituality is a political scenario devoid of specific cultural content.
}

Although spirituality in Africa may be viewed as a political scenario, Africa Traditional Religion (ATR) and spirituality are very much intertwined. Tshaka (2016:95) even argues that Africa is a creation of the West. Mbiti (1991:17-19) describes ATR as incorrectly called 'ancestor worship', 'superstition', 'animism' or 'paganism', 'magic' or 'fetish'. However, there are different opinions on this from other African scholars such as Amanze (2011), arguing that the spirits of the ancestors freely interact with the living; Nürnberger (2007) who describes the importance and embeddedness of ancestor veneration in African spirituality; Turaki (2001) who describes the uniqueness of Christ; and Bediako (1995) describing Christianity in Africa and from an African perspective. Although there are no sacred writings on ATR, it is recognisable in almost every aspect of the life in Africa. Mbiti (1991:20-30) indicates that it is found in rituals, ceremonies and festivals of Africans, in shrines, sacred places and religious objects, in art and symbols, music and dance, proverbs, riddles and sayings, names of people and places, myths and legends, beliefs and customs - indeed in every aspect of life. Amanze (2011:1) describes the 'six marks of authentic spirituality namely: contemplative awareness, effective action in the world, emphasis on community, a disposition to openness, non-dualistic thinking, and discernment', indicating that African spirituality adheres to these six marks. The article use these six marks to describe Africa's traditional spiritual phenomena and indicating the influence on African families.

\section{Contemplative awareness}

Amanze (2011:3) indicates that spiritual awareness requires listening, which specifies a state of mind that enables us to open our hearts to listen to God. Nürnberger (2007:42) notes that even in the 21st century South Africa 'millions of Africans still turn to hundreds of thousands of diviners and healers when in trouble, and these claim to act in the authority and power of the ancestors'; thus, Africans are not only listening to God. When African parents become aware of 'unnatural' ${ }^{2}$ or fearful behaviour of children or family, they will always consult with the spiritual intercessor (in many instances before any other action is taken), which could be either the sangoma or the prophet, to determine whether the child or family member is called by the ancestors to become an intercessor, or whether the child is cursed or a witch. Before we judge, we need to listen to Ilo (2017:21) who calls for humility through listening to become aware of people's agony, calling it vulnerable mission or mission of the wounded. It may then be said that (African) spirituality includes at least to listen to the living God, to the living dead (ancestors or 'authoritative deceased') and to the living people.

\section{Ancestors}

At least the following two important characteristics of African spirituality and beliefs are relevant and important for our topic, namely man is viewed as the centre of the universe (Mbiti 1991:43-44) and the fact that God is viewed as 2.The word unnatural is used by lack of a proper descriptive word for dreams or day dreaming, leading to fear or asking questions about ancestors. 
enigmatic (Mbiti 1991:59). Although Mbiti (1991:60) describes worship as 'renewing contact between people and God, or between people and the invisible world', it is clear from Nürnberger (2007) that:

Communication with the Supreme Being is, in the great majority of cases, not deemed possible, not even desirable, because his 'weight' is too mysterious and too massive to be amendable for human understanding and manipulation. (p. 32)

Because of this, Africans make use of intermediaries in the form of ancestors during worship. Therefore, worship, which is described as prayers, sacrifices and offerings, and singing in dancing, is focussed on pleasing or making contact with the intermediaries or ancestors, or the invisible or spiritual world. An ancestor, as the 'head father' of a clan or tribe, functions as basis of unity, community and existence (Turaki 2012:62). As a father, he has positive powers such as to love and protect, and negative powers such as to curse and bring misfortune (Nürnberger 2007):

Ancestors are not normally requested to carry the sacrifices, prayers or petitions of their offspring's upwards to higher ancestral authorities, and finally the Supreme Being. Nor do ancestors speak in the name of the Supreme Being when they make their intention of their displeasure known. In practical terms they are themselves the authorities with whom one relates ... (p. 33)

From the above, the conclusion is made that ancestors are worshipped. This is also in line with the understanding that Africa traditionalism is related to authority rather than time. Thus, in ancestral hierarchy 'higher up' also means 'earlier' (Nürnberger 2007:39). It is in light of this that the elderly will determine the life of the community, while the youth has to obey and keep quiet. Therefore, decisions are not made about the possible consequences it could have in future, but based on what has always been done (Nürnberger 2007:39).

\section{Spirits}

Reality and destiny in Africa is also closely linked to the spiritual world and the spirits (Turaki 2001:60). Mbiti (1991:70-81) describes the different spirits in the African tradition as follows: nature spirits from the sky (sun, moon, stars, rain, wind, thunder, lightning, et cetera) and the earth (mountains, trees and forests, metals, water in different forms like ponds, rivers, waterfalls, et cetera). It is important to note that not all African people believe in sky and earth spirits, and believers do not always attend to them with prayers and offerings. The sky and earth spirits rather help people understand things that are happening around them in the world, and in many instances, this will be taken into account when a newborn is named (Mbiti 1991:92-95).

A second group of spirits, which Mbiti (1991) describes, are human spirits - again in two groups: those who have passed away long ago and those who have died recently. The spirits of the distant past are presented in folk stories (Mbiti 1991):

... a literary device by means of which people caricature human life, satirize one another, make comments on society, and give an outlet to their feelings of fear, hatred or frustration, without the danger of offending anybody. ... the idea of these spirits serves an important social and psychological purpose through the literary form. (p. 76)

Some of the spirits of the most outstanding leaders of the past are also raised in myths and rituals to the status of divinities and even portrayed as God. It is important that children are introduced to these myths through storytelling and are included in the rituals and different ceremonies, as it keeps the ancestor 'alive'. An ancestor only has authority and belonging as long as he is recognised by his offspring (Nürnberger 2007:25). Therefore, in general people fear the spirits of the unknown people of the distant past, as they can be described as 'ghosts'. 'Some diseases, such as meningitis, lunacy, and the condition of being deaf and dumb, are associated with spirits of this kind in some societies' (Mbiti 1991:77).

The deceased of four or five generations ago are regarded as recently dead and are referred to as the 'living dead' to distinguish them from the 'ghosts'. These spirits are active in the lives of the living family members through dreams and visions, and when someone is sick they are contacted through rituals or a diviner to establish who caused the illness and to correct the matter through the requests of the 'living dead'. It is especially in illness and healing that the spiritual and physical worlds are viewed as one.

\section{Effective action in the world}

True spirituality does not withdraw from the world; it is not an escape from reality, but rather an engagement with reality such as in illness. Although African beliefs and religion are not described in sacred books, it is written in the lives of the people performing different rituals and attend different festivals. A ritual or rite 'is a means of communicating something of religious significance, through word, symbol and action. Therefore, a ritual embodies belief or beliefs' (Mbiti 1991:131). Many rituals and festivals include the children in a very direct way, for example birth rituals, name giving and initiation. According to Oduro et al. (2008:21-27), one of the main functions of African religion is to link the world of the dead with the world of the living, and as such, ensure harmony in the community. Therefore, salvation within African religion has to do with the needs of life, which include 'wellbeing, healing and protection against evil powers' (Oduro et al. 2008:26). Authentic spirituality is thus action orientated in an effort to heal the world and its brokenness, because there are 'little distinction between the sacred and the profane, between earthly and eternal salvation' (Oduro et al. 2008:27). The action that may be expected from spirituality is caring for others, transcendence and seeking goodness, truth and forgiveness (Mwambazambi \& Banza 2014:2). In connection to reality, African 'spirituality is often expressed in celebration. People celebrate life. They celebrate faith. They celebrate death. They celebrate suffering. Life is governed by a spirituality of intimacy and connection' (Ilo 2017:19).

Not all religious people are being spiritual, while others are spiritual without being religious. Ilo (2017:19) describes the 
true picture of Africa as 'a multiplicity of human experience held together by a common African spirituality based in the connections between people', which brings us to the emphasis on the community.

\section{Emphasis on community}

In Africa, life is part of community; in other words, African spirituality is not individualistic but communal. 'The community is responsible for the preservation and continuity of traditions and charisms' (Amanze 2011:3). In an African worldview, there is no life or spirituality outside the community and therefore children are cultivated by social interactions with siblings and age groups. The need for belonging is critical, as it determines the 'nature' of the human being. Oduro et al. (2008:21) describe the main function of African religion as to link the world of the ancestors with the world of the living, creating harmony in the community as well as the sense of belonging. Related to this belonging, every community member's status and role is determined through age, gender and seniority. 'Individuals are not entitled to go beyond their particular spheres of competence', and '[I]n compound societies the spiritual order reflects the social order, indicating that it is an order of power and authority' (Nürnberger 2007:23).

\section{Importance of family in African spirituality}

African children are brought up with the understanding that 'marriage is viewed as the sacred duty which every normal person must perform' (Mbiti 1991:104), because it leads to family and belonging. Marriage is also the meeting of the three phases of human life: the departed, the living and those to be born. African spirituality informs people that, through marriage and childbirth, the effects of death are reduced and neutralised. Mbiti (1991:110-115) describes several meanings and purposes of marriage such as the obligation to bear children; to be a uniting link within the rhythm of life; to contribute to the building of a family; to develop new relationships between family members; to ensure remembrance of parents after death; to regain a loss of immortality; to bring people together; to give a person or family status in society; to give a person 'completeness'; and to create good personal qualities.

It is clear from the above that the understanding of marriage and family in Africa is a much broader and more holistic concept than family from a Western perspective. Although there is no one definition of family, the concept of family in Africa includes not only the living, but also the deceased and even those to be born. In short, this may be described as Ubuntu. The understanding of Ubuntu is 'I am because you are'. It is thus understood that a person only lives through other persons regarding keeping the ancestors alive as was described above. Although there are much truth in Ubuntu, I understand it as a spiritual concept, because it clearly involves the ancestors. It is in this regard that my understanding is: 'I am and you are because He (God) is' (Knoetze 2017:1).

\section{A disposition to openness}

Preconceived notions and ideas must be set aside, as Africans are prepared and willing to enter into dialogue with other experiences, ideas, relationships and revelations. Spirituality requires an ecumenical approach that involves an active opening of oneself to other views and religions, listening to positions and perspectives other than one's own as most Africans have done. The best example of this may be found in the religious institutions, for example in the African Independent Churches (AICs), as it is representing a wide range of religious understandings and practices 'ranging from groups only one step removed from traditional African religious reality to Christcentred, Spirit-led, biblical orientated communities of faith' (Oduro et al. 2008:6). Many African people see Christianity as the fulfilment of ATR. The rational for many in Africa to anchor Christian spirituality on African spirituality is based on the incarnational nature of the church as the concrete manifestation of the kingdom of God on earth which began when the Word came down from heaven, took human flesh, became man and dwelt among us (Jn 1:14). Amanze (2011) argues:

... the logic of grounding Christian spirituality on African spirituality lies also in the fact there is a correlation between African spirituality and the unprecedented growth of Christianity in Africa from the time of its inception to the present day. There is ample evidence that African spirituality has been a catalyst of Christian presence on the African continent. (p. 9)

From the side of Africa, there is an openness to the Pentecostalcharismatic churches with the emphasis on the healing by the Holy Spirit and by faith. Although the Holy Spirit is completely different from the spirits in ATR, it resonates well with the African psyche, because it addresses the needs of Africa.

\section{Non-dualistic thinking}

Bujo (2015:1) states clearly that "the definition of "person" in Africa is certainly not coterminous with Western definition', and that Africans do not think in 'either/or' but rather in 'both/ and' categories and therefore include the visible and invisible community. In the African worldview, reality is a whole that is more than the sum of its parts, as everything is in interaction and inter-reaction. In this context, the role and importance of children must not be underestimated - they are the link between the past, the present and the future, as argued above. The traditional African worldview sees all life as spiritual, and the spirit world controls everything including the physical world. 'Everything has a religious narrative' (Ilo 2017:20). Therefore, man lives in constant fear of the spirit world (Oduro et al. 2008:21; Van der Walt 2003:183). Given that African spirituality does not separate or distinguish between physical and spiritual, the African-Initiated Churches (AIC) have an 'open invitation to Africans to bring their fears and anxieties about witches sorcerers, bad luck, poverty, illness and all kinds of misfortune to the church leadership' (Oduro et al. 2008:75).

\section{Discernment}

Maluleke (2001:27) makes the statement that influential missionary councils and pioneer missionaries had generally condemned Africa's past religious traditions. If Africa's past religious traditions are understood according to Amanze's remarks (2011), it clearly becomes a question of discernment: 
The concept of God, the biblical account of creation, the concept of ancestors, belief in life after death, sacred nature of fire, the role and importance of dreams and visions, prominence given to child bearing, the dominant role of prophecy and divination, the dominance of magic and miracles, the nature and role of sacrifices, the concept of shame, purity and impurity, the sanctity of human life, the community as the family of God, the evil nature of witches, to name but a few, are fairly common both in biblical spirituality and African spirituality. As Diarmaid MacCulloch has observed, these similarities make the African people to take the Biblical message seriously for everything is there that they want to hear. (p. 10)

Discernment implies that we need to make a clear distinction between a biblical spirituality and the uncritical accommodation or assimilation of the phenomena of African spiritualities. A biblical perspective will be one which is:
... always prophetic and arising always out of a genuine encounter between God's Word and His world, and moves towards the purpose of challenging and changing the situation through the rootedness in and commitment to a given historical moment. (Amanze 2011:11)

A biblical spirituality will always be founded in a Trinitarian God and not only in a creational God who resonates with Abrahamic faiths and ATR. It will thus be appropriate to work with a hermeneutics of suspicion when we are dealing with any spirituality to discern whether it is from Christ or not. In the first letter of John, he is encouraging the believers: 'Dear friends, do not believe every spirit, but test the spirits to see whether they are from God, because many false prophets have gone out into the world' (1 Jn 4:1), and the Spirit that is from God, confesses Jesus as the Son of God. Discernment is especially important regarding children in Africa, because many of them are killed or regarded as witches because of traditional beliefs or announcements of spiritual intercessors. For example, Mbiti (1991) writes:

... twins were considered to be a sign of misfortune, and one or both would be killed, or the mother would be killed. In other parts of Africa, the twins would be allowed to live, but people regarded them as having special powers from God. (p. 95)

Discernment also has to do with cultural practices like Ukuthwala that will be discussed later.

\section{Globalised Africa spirituality: An overview \\ Introduction}

'The dominant globalism of the nineteenth century was colonialism with its dynamics as the conquest, commerce, and sometimes civilisation (mission)' (Myers 2017:56). In this section, globalisation and its influence will be discussed with a focus on Africa from the perspectives of Myers (2017) in his book, Engaging globalization.
Globalisation is known as colonialism in the third world for several centuries and is even today seen 'as a globalisation by a minority' (Myers 2017:40). Bosch (1991:305-306) reflects on the relationship between colonialism and mission, quoting statements such as: 'To colonize is to missionize', and referring to the three ' $C$ 's' of colonialism, namely Christianity, commerce and civilisation. It is clear that, within our previously stated understanding of spirituality, we may speak of globalisation as a form of spirituality to be found also in the specific context of Africa. Many white and black people in Southern Africa view globalisation as 'the way to the promised land of material progress for the poor, democracy, human rights, and eventual peace' (Myers 2017:35). Contributing to this thinking is some of the domains of globalisation such as technology, a new culture of consumerism and large numbers of human beings. Especially the 'emerging adults' in Africa are 'captured' by these dynamics. This is noticed in the way technology is changing, for example, the traditional African and Christian culture as well as the functioning of families. This was dealt with by Knoetze (2017) in an article titled, 'Who are the disciples? Identity perceptions about millennials and the church'.

Influenced by a modern worldview, people from the West have assumed that they were improving the human conditions in Africa by the belief that 'people with enough intelligence, money, and technology can and will refine and recreate our world for the better' (Myers 2017:54). However, even more than before, Africa is realising that the international community is not able to create the promised land of peace and wealth, and that all is not well with modernity (Nürnberger 2007:212). If lingering poverty is to be eliminated and all people must have the same human rights, and other so-called social ills in Africa must be sorted out, it is increasing normative for African people 'to understand themselves as actors who can and should do something about their futures and the world they live in' (Myers 2017:51). It needs to be realised that no one is in control of globalisation, and no one knows the outcomes of globalisation. In Africa, the influence of globalisation on economics and governance is indeed questionable, because it seems to contribute to increase social ills, for example financial and spiritual poverty. The gap between the rich and the poor countries and individuals are increasing as well as the gap between the poor and the governments. However, it needs to be realised that, although no one is in control of globalisation, globalisation 'can be shaped by a widely held ideological or theological set of beliefs, or what some call "globalisms"' (Myers 2017:53). 'Globalisms' are human concepts clarifying connotations, and changing as the world changes.

\section{Modernity}

When modernity is understood as part and parcel of globalisation, Nürnberger (2007) gives the following critique:

... modernity has often been the 'misdeeds' of the past: it was the force behind colonialism and imperialism; it was oppressive and exploitive; it looked down upon other cultures; it dismantled the foundations of the indigenous cultures and belief systems; it had 
an unrealistic perception of progress; it was based on restrained greed, and so on. (p. 212)

What follows are two examples of how globalised Africa spirituality influenced families. The direct and indirect impact of globalisation on the breakdown of the traditional family structures and culture has been massive. In 2015, it was reported in a local newspaper, Beeld, that $61 \%$ (886 202) of birth registrations had no information about the father (October 2015:1). The Daily Maverick of 14 August 2018 reported that 'In the age group between 15 and 24 the unemployment rate is $67 \%$ and $43 \%$ for those from 25 to 34 ' (Bagraim 2018). Bagraim discusses this in line with the influence of labour legislation, especially on the farms and in the mining industry as well as technology used in the mines and farms decreasing labour opportunities. His argument is that good intentions had bad consequences in practice. Linking labour legislation and technology back to globalisation, the influence of globalisation's dynamic domains of economy and governance has a direct influence on Africa's families. Fathers, as role models, have disappeared in many instances. Except for those children who grow up without fathers, a large group of children grow up in child-headed households for different reasons. Some are by choice; others had no choice, and they do it to survive. Within a context where 1.6 million people died of human immunodeficiency virus (HIV) and acquired immunodeficiency syndrome (AIDS) in 2007 (Tsegaye 2009:8), children are socialised powerfully through peer-influences many by means of their cell phones. Instead of belonging to a family, youth create their own family in the form of gangs. Instead of going to school, they become teachers in the street schools. Especially youth who grow up without fathers, no longer respect authority. Traditional values and constraints (e.g. on sexual behaviour) disappear. Young women emancipate themselves and outperform men. Men get into an identity crisis, because their traditional role collapses. They often simply abscond, begin to drink and turn to violence.

\section{Ukuthwala: Cultural practices misused}

It seems as if the idea of an African Renaissance is fostered by westernised African academics who try to regain an African identity that integrates modern aspects, but holds its own against the dominance of Western culture. A second example of how globalisation influences African families is when old traditions are turned into unhumanitarian actions. Popular postmodernity has created the freedom and the space for traditional cultural patterns to express themselves in unethical ways. One such an example would be the traditional bride abduction, known in the Zulu language and culture as 'ukuthwala'. Bride kidnapping is known in at least 17 countries from the eastern world (China) to America (Mexico) to Russia and Southern Africa. In this, 'custom' girls from as young as 10 years of age are taken to be married to older men (Modisaotsile 2013):

However, the way it is practiced currently is illegal and harmful to the wellbeing of young girls. Young girls usually suffer physically due to their bodies' response to premature sex, including pregnancy. They are also at risk of sexually transmitted infections and emotional disturbance and in some cases their educational development is disturbed too. (p. 1)

Although the South African government has passed a law to protect children from harmful practices, the 'ukuthwala' is still evident in some parts of South Africa such as in KwaZuluNatal. The dangers of postmodern emancipation are that detrimental aspects (such as sorcery, spurious divination, the abuse of magadi or ilobolo, the violence of initiation schools, etc.) regain their legitimacy, and that the rigour of the modern economy is discarded.

\section{Some influences of spiritualities}

The influence of spirituality on African families will be discussed from a Christian point of view. It is, however, important to realise that religions and spirituality are not fixed systems of meaning, but subject to internal transformation and external impact. Important for the purpose of this article is 'not the ostensibly "original" form of an African spirituality, which may or may not have been practised centuries ago, but its present, living form' (Nürnberger 2007:35).

The Bible introduces us to different compositions of families and spiritualities. This relates with many of the compositions of African traditional families, for example the extended family, the nucleus family, the single mother, et cetera. In this regard, it may be said that African traditional spirituality has not influenced the composition of families as negatively as spirituality associated with globalisation has done. Globalisation has contributed in different ways to influence the composition and functioning of African families, for example to become more individualistic and forsake their previously accepted social roles as determined by their culture. The important role of community, or if you wish, Ubuntu, has been depleted by globalisation, for example in South Africa, $5 \%$ of the population have a prevalence for pathological internet use (Ogachi, Karega \& Oteyo 2018:202). However, globalisation also contributed to the migration of Africa families and individual parents from rural areas to cities where many of them ended up in informal settlements, living in poverty with little or no support system. 'Gone is the value of stable sexual relationships, marital faithfulness and the family as protective and formative nest for the new generation' (Nürnberger 2007:227). The technological domain of globalisation such as mobile phones and television screen may 'undermines the health, creativity, community and spirituality of entire families including children' (Nürnberger 2007:227). On the other hand research in 'sub-Saharan Africa indicates that mobile phones may be very important tools for social connection, banking, for accessing help and health care, income generation, safety and even resistance and activism' (Pearson et al. 2017:1).

Globalisation also contributed to the fact that (African) people shop around in the religious market place. This leads to taking elements from different 'religious places', try it out, and when they get bored they dispose of it. Although there might also be positive aspects to this, the main problem is 
that, in the postmodern globalisation, there are no evaluation criteria - everything goes. This is even truer within some of the current forms of spirituality in South Africa where pastors would ask money for prayers and let people participate in activities such as drinking petrol and spraying them with insect repellents. Spiritual influences from traditional Africa, which are problematic to African families, are aspects of spiritism, magic, fear of sorcery and suspicion of witchcraft. A globalised African modernist and postmodernist do not believe in these things but 'where such phenomena seem to be oppressive they should be subjected to deconstruction' (Nürnberger 2007:229). Traditional Africa spirituality in the form of dynamistic - magical beliefs - destroys human relationships in communities and families. People who are assumed to participate in sorcery may be ostracised, tortured or killed. It is not uncommon in (South) Africa to read of ritual killings to obtain potent body parts for 'therapeutic purposes'. For the same reason, babies and virgins are raped to be cured from HIV. Turaki (2006:89-96) clearly relate spiritual and power phenomena to each other, and it is in their acquisition for power that many Africans are exploited by some diviners and so-called 'prophets'.

It must thus be concluded that traditional as well as globalised Africa spirituality may have the following influences on African families: Traditional African spirituality may create fear in African families (Nürnberger 2007:25; Oduro et al. 2008:21); traditional African and globalised African spirituality may physically impoverish the African family; globalised African spirituality may destroy the community within the African family through, for example, technology that creates an idealistic cyber world in which young people live; fathers and/or siblings migrate to cities or other countries for economic reasons and thus weaken the whole family concept, while African traditional spirituality may encourage good family relations and strengthen families; and initiation rites in traditional African spirituality may harm and cripple a young African in a spiritual and physical way and determine the future of their family life.

These are only some of the influences of Africa spirituality on African families. The most important is to recognise that not any of these spiritualities brings salvation into the family as biblically understood. Oduro et al. (2008:27) indicates that, in African religion, salvation has to do with protection against all evil in the here and the now, and although this is biblically sound, biblical salvation also includes salvation from sin, which is missing in the ATR. Turaki (2012:xiii) states that many African Christians have an understanding of sin made up by popular opinions mixed with traditional views and guesswork, and as such, they 'cannot explain what sin is, [and] how it affects humans and society'. The implications and challenge of these spiritualities for the missional church in Africa are not dealt with in this article, but need to be worked out.

\section{Conclusion}

When talking of spirituality from a Christian point of departure, spirituality is primarily a religious term with a focus on salvation. The understanding of salvation includes the characteristics of spirituality as mentioned by Amanze (2011). It includes a contemplative awareness to listen to God, to the culture and to the people. Spirituality, which focuses on salvation, does not withdraw us from the world, but helps us to live with hope in this world and gives meaning to our lives. Christian salvation may no longer only be viewed in individualistic terms, but must help us to live within broken communities. 'Salvation does not [only] come through change in individuals but through the termination of perverted and unjust structures' (Bosch 1991:396). A spirituality that focuses on salvation has a disposition to openness, because it is not afraid or focused on the self, but on the kingdom of God. Salvation may never again only be spiritual; it is non-dualistic, it is holistic and it is redemptive. It is not only about 'where do I find a merciful God', but also about 'How can we be merciful neighbours to each other' (Bosch 1991:396). Salvation and redemption is about living the grace, righteousness and internal life in Jesus Christ (Turaki 2012:105). When spirituality is focussed on salvation, it includes discernment 'It is Jesus Christ who "accomplishes all salvation". No one can complete his work if he does not achieve it himself' (Bosch 1991:398). It is concluded that there are no one African spirituality that influences African families, but rather different spiritual phenomena in Africa that influence African families in different ways. Spirituality does not only influence families spiritually, but also physically.

\section{Acknowledgements Competing interests}

I declare that I have no financial or personal relationships that may have inappropriately influenced me in writing this article.

\section{Author's contributions}

I declare that I am the sole author of this research article.

\section{Ethical considerations}

This article followed all ethical standards for research without direct contact with human or animal subjects.

\section{Funding information}

This research received no specific grant from any funding agency in the public, commercial, or not-for-profit sectors.

\section{Data availability statement}

Data sharing is not applicable to this article as no new data were created or analysed in this study.

\section{Disclaimer}

The views and opinions expressed in this article are those of the authors and do not necessarily reflect the official policy or position of any affiliated agency of the authors. 


\section{References}

Amanze, J.N., 2011, 'Contextuality: African spirituality as a catalyst for spiritual formation in theological education in Africa', Ogbomoso Journal of Theology XVI(2), 1-24.

Bagraim, M., 2018, 'Who speaks for the unemployed?', viewed n.d., from https:// www.dailymaverick.co.za/article/2018-08-14-who-speaks-for-the-unemployed/

Bediako, K., 1995, Christianity in Africa: The renewal of a non-Western religion, Orbis Books, Maryknoll, NY.

Bosch, D.J., 1991, Transforming mission: Paradigm shifts in theology of mission, Orbis Books, Maryknoll, NY.

Bujo, B., 2015, Foundations of an African ethic, Crossroad Publishing Company, New York, NY.

Ilo, S.C., 2017, 'I am through you', U.S. Catholic, September, 18-22.

Knoetze, J.J., 2017, 'Who are the disciples? Identity perceptions about millennials and the church', Verbum et Ecclesia 38(1), a1718. https://doi.org/10.4102/ve.v38i1.1718

Maluleke, T.S., 2001, 'Identity and integrity in African theology: A critical analysis', Religion and Theology 8(1), 26-41. https://doi.org/10.1163/157430101X00026

Mbiti, J.S., 1991, Introduction to African religion, 2nd edn., Waveland Press, Long Grove.

Modisaotsile, B., 2013, Ukuthwala: Is it culture correct or culture corrupt?, viewed 12 January 2018, from https://www.pambazuka.org/arts/ukuthwala-it-culturecorrect-or-culture-corrupt

Mwambazambi, K. \& Banza, A.K., 2014, 'Four-dimensional conversion for spiritual leadership development: A missiological approach for African churches' HTS Teologiese Studies/ Theological Studies 70(3), Art. \#1953, 9 pages. https:// doi.org/10.4102/hts.v70i3.1953

Myers, B.L., 2017, Engaging globalization: The poor, Christian mission and our hyperconnected World, Baker Publishing Group, Grand Rapids, MI.
Nurnberger, K., 2007, The living dead and the living God, Cluster Publication, Pietermaritzburg.

October, A., 2015, '886202 babas gebore, maar waar is die pa's?', Beeld, 02 September, p. 1.

Oduro, T., Pretorius, H., Nussbaum, S. \& Born, B., 2008, Mission in an African way, CLF Wellington.

Ogachi, F.M, Karega, M. \& Oteyo, J.S., 2018, 'Relationship between depression and pathological Internet use among university students', Cypriot Journal of Educational Science 14(2), 201-207. https://doi.org/10.18844/cjes. v14i2.3123

Pearson A.L., Mack, E., Namanya, J., 2017, 'Mobile phones and mental well-being: Initial evidence suggesting the importance of staying connected to family in rural, remote communities in Uganda. PLOS ONE 12(1), e0169819. https://doi. org/10.1371/journal.pone.0169819

Tsegaye, S., 2009, Orphanhood in Africa: Old problems and new faces, The African Child Policy Forum, Addis Ababa.

Tshaka, R.S., 2016, 'How can a conquered people sing praises of their history and culture? Africanization as the integration of inculturation and liberation', Black Theology 14(2), 91-106. https://doi.org/10.1080/14769948.2016.118 5841

Turaki, Y., 2001, The unique Christ for salvation. The challenge of the non-christian religions and cultures, International Bible Society, Nairobi.

Turaki, Y., 2006, Foundations of African traditional religion and worldview, WordAlive Publishers, Nairobi.

Turaki, Y., 2012, The trinity of $\sin$, WordAlive Publishers, Nairobi.

Van der Walt, B.J., 2003, Understanding and rebuilding Africa, Printing Things, Potchefstroom.

Wellman, W. Perkins, G. \& Wellman, N., 2009, 'Educational leadership: The relationship between spirituality and leadership practices', Spirituality in Higher Education Newsletter 7, 1-6. 